BENHA VETERINARY MEDICAL JOURNAL, VOL. 4, No. 3: 338-354, AUGUST 2018

A SPECIAL ISSUE FOR THE $6^{\text {TH }}$ SCIENTIFIC INTERNATIONAL CONFERENCE

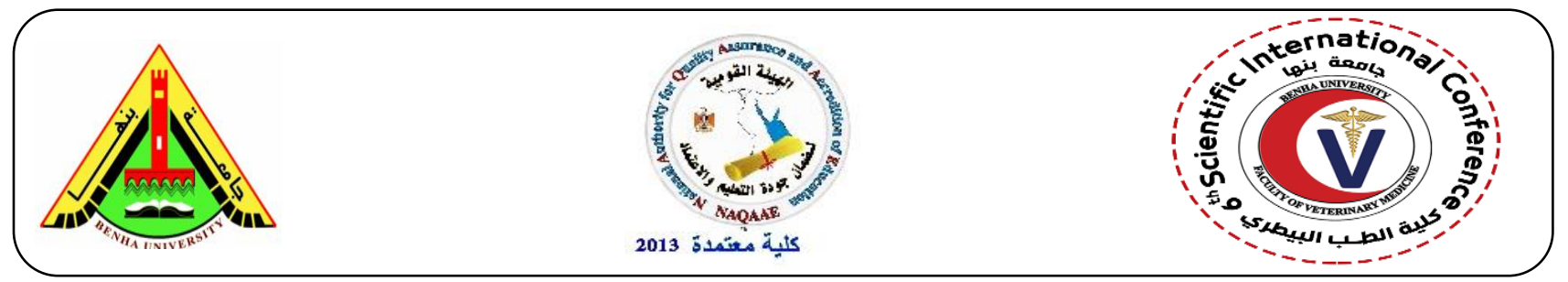

\title{
A Phylogeny of Envelope protein like gene of Lumpy skin disease virus, Egypt, 2014
}

El-kady. G.HE.M*, G.F. El-Bagoury, E.M. El-Nahas and A.S. El-Hab3baa

Virology Department, Faculty of Veterinary Medicine, Benha University, Egypt.

Corresponding Author: El-kady.G.HE.M, E.Mail address: gehadelkady.viro@gmail.com ;

dr.gehadhossam@yahoo.com;gehad.mohamed@fvtm.bu.edu.eg

Mobile phone (+2): 01062510749_01152321564

\section{A B S T R A C T}

Numerous of Cases of skin nodules eruptions tied to lumpy skin disease virus (LSDV) are becoming more frequent in Qailubia Province, Egypt amongst cattle populations in 2014. In this study, a strain of LSDV (LSDV-Elkady-2014) associated with that outbreak was isolated from scabs of clinically infected Frisian cattle on chorioallantoic membrane (CAM) of specific pathogen free embryonated chicken eggs (SPF-ECEs). The isolate induced hemorrhage, enlarged liver, slight heart hypertrophy of chick embryos, with a pock lesion on CAM. Identification of LSDV-Elkady-2014 isolate was confirmed by histopathology, electron microscopy (EM), immunoflourescence (IF), and polymerase chain reaction (PCR) targeting LSDV envelope protein-like gene. Based on the partial sequence analysis of LSDV envelope protein-like gene. LSDV strain was phylogenetically related to LSDV - NI-2490, LSDV/ NW/LW, and LSDV/2/slemani/Kurdistan/2014. In conclusion, LSDV is still circulated in Egypt, and the isolated strain induced characteristic properties on chick embryos that were not previously recorded by LSDV.

Keywords: LSDV; chick embryo; EM; Phylogeny; Egypt

\section{www.bvmj.bu.edu.eg BVMJ Vol.34 No.3 :338-354}

\section{Introduction}

Lumpy Skin Disease virus (LSDV), a member of the genus Capri poxvirus, belongs to family Pox viridae with typical Poxvirus geomorphology and closely related to the viruses of Sheep pox and Goat pox as demonstrated by MacLachlan et al. (2011). The genome is a 150,000 bp long double-stranded
DNA, covalently cross-linked at the ends, similarly to other Poxviruses. Capri pox virus genomes sequences are highly conserved, and there is more than 95\% homology amongst LSD, Sheep pox, and Goat pox viruses as demonstrated by Kara et al. (2003). It causes an acute, subacute, or chronic disease of cattle, characterized by fever, multiple firm, circumscribed nodules in the skin of the 
affected animals, necrotic plaques in the mucous membranes, and generalized lymphadenopathy as well as demonstrated by Buller et al. (2006). It was transmitted by biting insects, especially blood-feeding insects, such as the mosquito as demonstrated by Chihota et al. (2001). There is a real danger that LSDV could spread from Africa to Asia and Europe via the Middle East, and vice versa as demonstrated by James et al. (1990).

In Egypt, LSD was appeared firstly among imported and native breed of cattle in Suez in 1989, the disease was spread rapidly and diagnosed after El tall El-Kbeer, Ismailia outbreak as demonstrated by James et al. (1990). Reappearance of LSD was observed by El-Bagoury et al. (1995) during Minia outbreak, during late summer and autumn of 2006 in different Egyptian governorates as demonstrated by Stram et al. (2008), and during 2010 in cattle and buffaloes at Qailubia Province as demonstrated by El-Nahas et al. (2001). In this study, a massive outbreak of suspected LSD in cattle population were observed in 2014 at Qailubia Province, Moshtohor. So, the aim of this study was a trial for isolation and identification of LSDV which incriminated in this outbreak amongst cattle population in Egypt (2014).

\section{Materials and methods}

\subsection{Clinical history and sample collection}

Between May and August 2014, cattle from different farms in Qailubia Province, Moshtohor and Shibin Elkanater, Egypt, were reported to have developed skin nodules. Most of the Friesian cattle had severe clinical signs where nodules and scabs scattered all over their body parts including vulva, teat, and forelimbs (fig1). History revealed that, the Friesian cattle were unvaccinated against LSDV. Skin scabs were aseptically collected either on $50 \%$ glycerol saline according to OIE (2010), or frozen until they were used for later study.

\subsection{Virus isolation in $C A M$}

Skin scabs homogenate was prepared in phosphate buffered saline (PBS, PH 7.4) with $100 \mathrm{U} / \mathrm{ml}$ penicillin and $100 \mathrm{mg} / \mathrm{ml}$ streptomycin. The homogenate was lysed by freezing and thawing three times, and the supernatant was purified by centrifugation at $6000 \mathrm{xg}$ for $5 \mathrm{~min}$ at $4^{\circ} \mathrm{C}$ and filtration through a $0.45 \mu \mathrm{m}$ pore-size cellulose acetate filter. SPF-ECEs after 9 days of incubation were inoculated with $0.2 \mathrm{ml}$ of the supernatant, which was dropped onto through CAM according to James et al. (1990). The sample was grown at least three times in CAM to increase the titer of the virus. The eggs were examined on a daily basis, terminating with 5-7days postinoculation. The embryos that died within the first $24 \mathrm{~h}$ were classified as a nonspecific deaths. Pathologoanatomic signs on chick embryos and CAM were recorded and subjected to LSDV identification. Both chick embryo (liver and heart) and CAM homogenate were prepared and passaged on SPF-ECEs for further confirmation.

\subsection{Histopathology}

Fresh inoculated CAM were collected, fixed in $10 \%$ neutralized buffered formalin, dehydrated, embedded in paraffin wax, and then sliced in $6 \mathrm{~mm}$-thick sections. Those sections were stained with hematoxylin and eosin (HE) and histopathologically examined by light microscopy according to Haligur et al. (2009).

\subsection{Transmission electron microscopy (TEM)}

A thin section of infected CAM was prepared for electron microscopy as previously described by Miller (1995). Where, the CAM was fixed in $4 \%$ buffered glutaraldehyde, post fixed with $1 \%$ buffered osmium, dehydrated in a graded series of ethanol solutions, and then 
embedded in an epoxy resin. Semi-thin sections were cut by Reichert-Jung Ultra-cut 701701 Ultracut Ultramicrotome, stained with toluidine blue, and examined by the light microscope. The selected ultrathin sections were mounted on copper grids, stained with urarnyle acetate and lead citrate, and examined with TEM (JEM2100-Joel-Japan).

\section{Immunofluorescence assay (IFA)}

CAMs and madin derby bovine kidney (MDBK) cells (produced by Ames, Iowa Laboratory, USA and it was obtained from Cell Culture Department, VACSERA, Agouza, Giza., Egypt, and maintained at Virology Department, Faculty of Veterinary Medicine, Benha University.

that infected by chick embryo homogenate were tested by indirect immunofluorescence assay (IFA) according to Davies (1971). LSDV infection was confirmed using the LSDV reference antisera (supplied by Department of Pox Virus Vaccine Research and Production, Veterinary Serum and Vaccine Research Institute, Abbasia, Cairo, Egypt) as the primary antibody and a FITC-labeled goat anti-bovine IgG (Kirkegaard and Perry Laboratories, 2 cessana court, Gaithersburg, Maryland 20879, USA). Cells were examined by fluorescent microscopy.

\subsection{DNA extraction, $P C R$, and sequencing}

DNA was extracted by using the QIAamp® DNA Mini and Blood Mini kits (Qiagen, USA) according to the manufacturer's instructions. The primers used were: \# LSD 5' GGGAAAAGGTAGAAAAATCAGGAGG-

$3^{\prime}$ (Forward), LSD $5^{\prime}$ -
CGCATCGGCATACGATTTCC-3`

(Reverse). The reaction conditions were: $94{ }^{\circ} \mathrm{C}$ for $5 \mathrm{~min}, 40$ cycles of $94{ }^{\circ} \mathrm{C}$ for $30 \mathrm{~s}, 52{ }^{\circ} \mathrm{C}$ for $30 \mathrm{~s}$, and $72{ }^{\circ} \mathrm{C}$ for $30 \mathrm{~min}$, and a final extension step of $72{ }^{\circ} \mathrm{C}$ for $7 \mathrm{~min}$.
The primers were specific for LSDV envelope protein-like gene, and kindly obtained from Dr. Wessel Dirksen, Ohio State University Research Foundation, 925 Coffey RD, 345 Goss Lab/ College of Vet MED, Columbus, $\mathrm{OH}$ 43210, USA (P.O \# RF01404362). The expected size of the PCR product was $137 \mathrm{bp}$.

\subsection{Sequencing}

For sequencing, PCR-product DNA was purified with QIAquick® PCR Purification Kit (Qiagen, USA) according to the manufacturer's instructions. The PCR primers were used for sequencing. Sequencing of the purified PCR products was performed by the manufacturer in BigDye ${ }^{\circledR}$ Terminator v3. 1 Cycle Sequencing Kit, P/N 4337456. The cycle sequencing was performed using applied biosystem, amp 9600 PCR system.

\subsection{GenBank Accession number \\ ELKADY_2014 (KU760905.1) \\ ELKADY/1/2014 (KX236310.2) \\ ELKADY/2/2014 (KX236311.1) \\ ELKADY/3/2014 (KX236312.1) \\ ELKADY/4/2014 (KX236313.1) \\ ELKADY/5/2014 (KX250367.1)}

\subsection{Bioinformatics}

Phylogenetic analysis was done by firstly applying Clustal W (http://www.ebi.ac.uk/clustalw/), and then the alignment *.an output file was used for performing the phylogenetic Neighbor-Joining $(\mathrm{N}-\mathrm{J})$ analysiswith1000 repeats of bootstrap tests analysis in MEGA 4.0 according to Tamura et al. (2007). All sequences used in the phylogenetic analysis are listed in Table 1.

\section{Results}

3.1.Virus isolation 
Pathologoanatomic signs of virus isolation were observed on CAMs by the $1^{\text {st }}$ passage and on the embryos by the $2^{\text {nd }}$ passage, and those changes continued till the $3^{\text {rd }}$ passage. CAMs were hemorrhagic and congested at the $1^{\text {st }}$ passage, and then pock lesions were detected in the form of stretched white line, which became more pronounced after 6 days of inoculation at $2^{\text {nd }}$ and $3^{\text {rd }}$ passages. The dead embryos were hemorrhagic, edematous, with enlarged and bloody liver, and clotted blood inside the heart with slight heart hypertrophy (fig_2,3) in comparison with negative control (fig_4).

\subsection{Histopathology}

The inoculated CAM showed a slight proliferation in the ectodermal and mesodermal cell layers with large eosinophilic intracytoplasmic inclusion bodies (fig 5).

\subsection{Transmission electron microscopy (TEM)}

The infected cells of CAM contained few virus particles that appeared ovoid in shape, with rounded ends (fig 6).

\subsection{Immunofluorescence assay (IFA)}

CAMs and MDBK cells that infected by chick embryo homogenate were tested positive by IFA. Specific intracytoplasmic yellowish green fluorescent granules emitted from the infected cells (fig 7, 8).

\section{4. $P C R$}

The primer targeted the LSDV envelope protein-like gene was succeeded to amplify the specific products (113bp) from the extracted DNA of the original skin sample, infected CAM, and embryo liver using PCR (fig 9).

\subsection{Sequencing and phylogenetic analysis}

The partial sequence analysis and alignment report of the envelope protein-like gene for the recent local LSD virus strain from different sources using clustal w showed high nucleotide similarity of the strain in their different sources with identity percent from 98 to $100 \%$. The isolate sources (CAM and the embryo source) show $100 \%$ and $98.9 \%$ homology with their skin original samples respectively. The embryo source shows $98.9 \%$ homology with CAM source (fig 10). The phylogenetic tree was constructed to calculate and examine the evolutionary relationships of the sequences, in which the length of the horizontal line connecting one sequence to another is proportional to the estimated genetic distance between the sequences (fig 11). 
A Phylogeny of Envelope protein like gene of Lumpy skin disease virus, Egypt, 2014

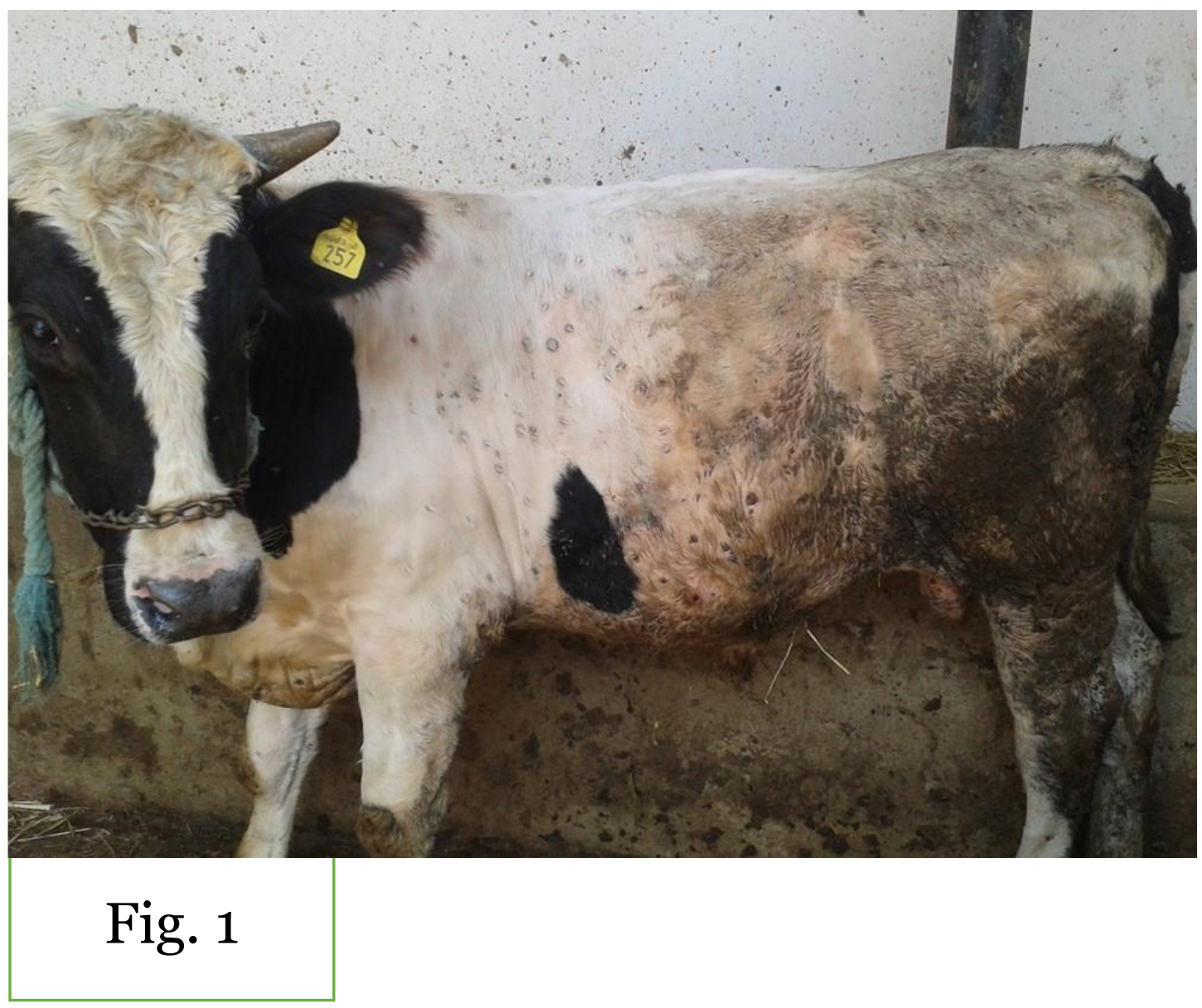


El-kady et al., 2018, BVMJ Vol.34 No.3 :338-354

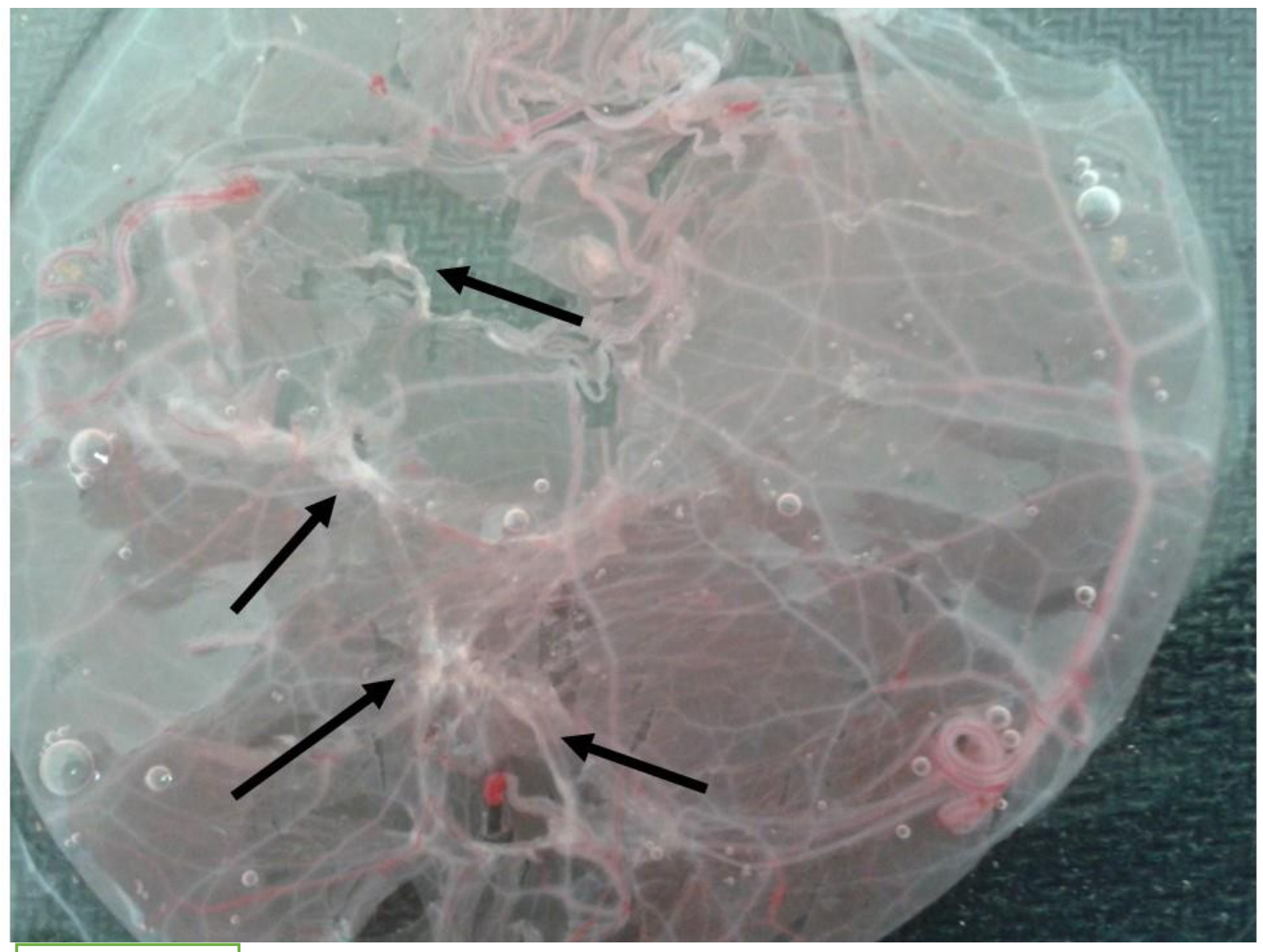

Fig.2

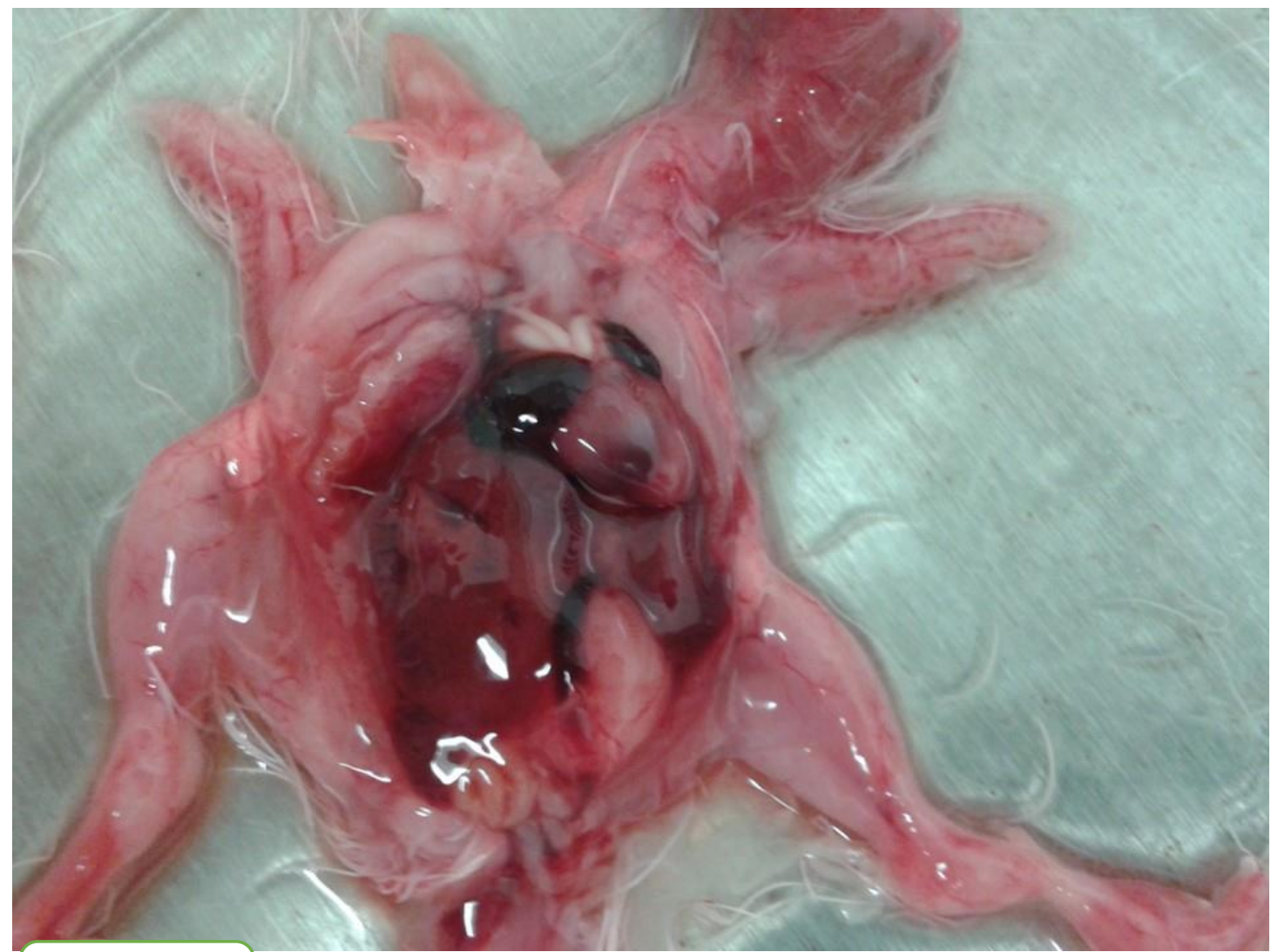

Fig. 3 


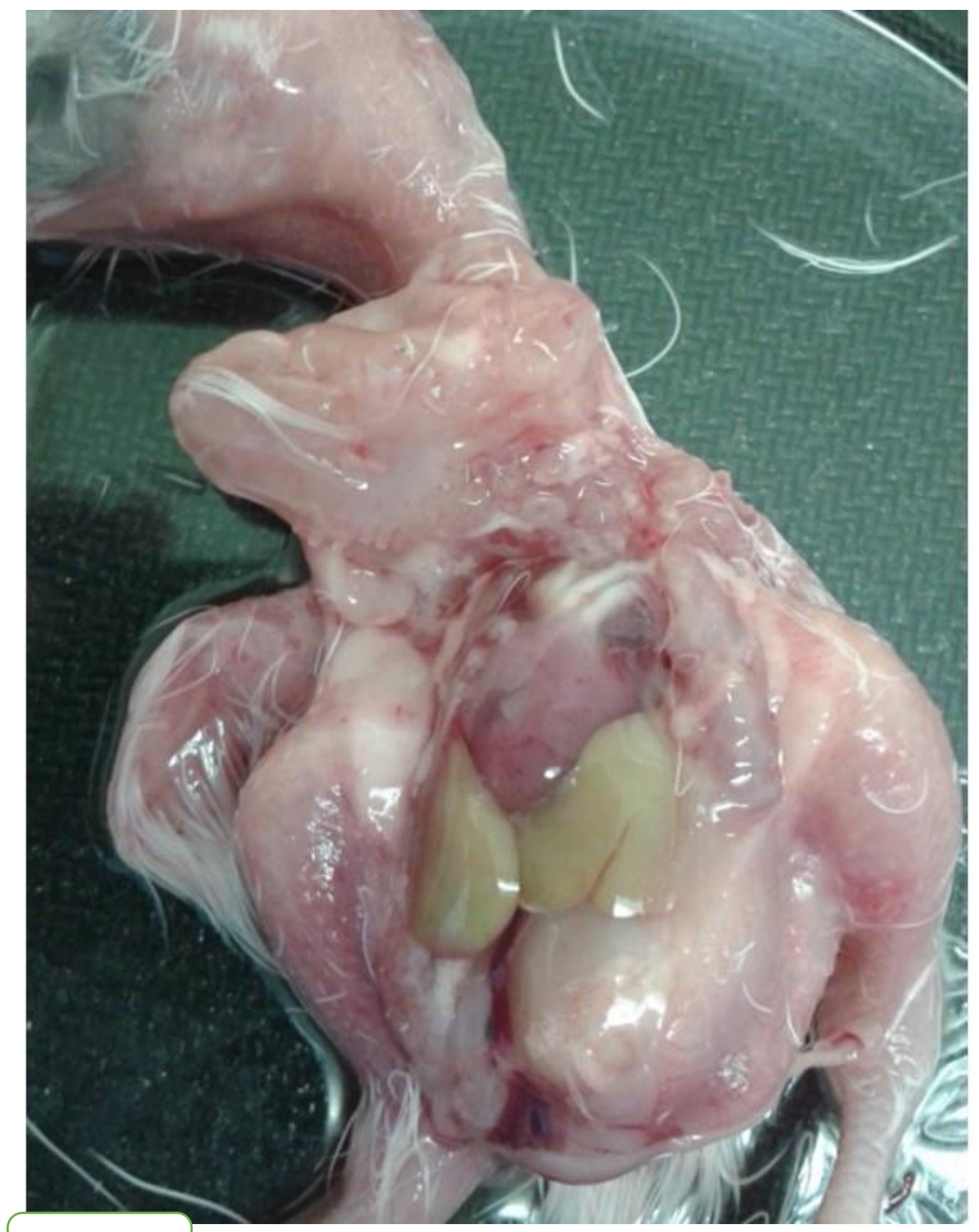

Fig. 4 
El-kady et al., 2018, BVMJ Vol.34 No.3 :338-354

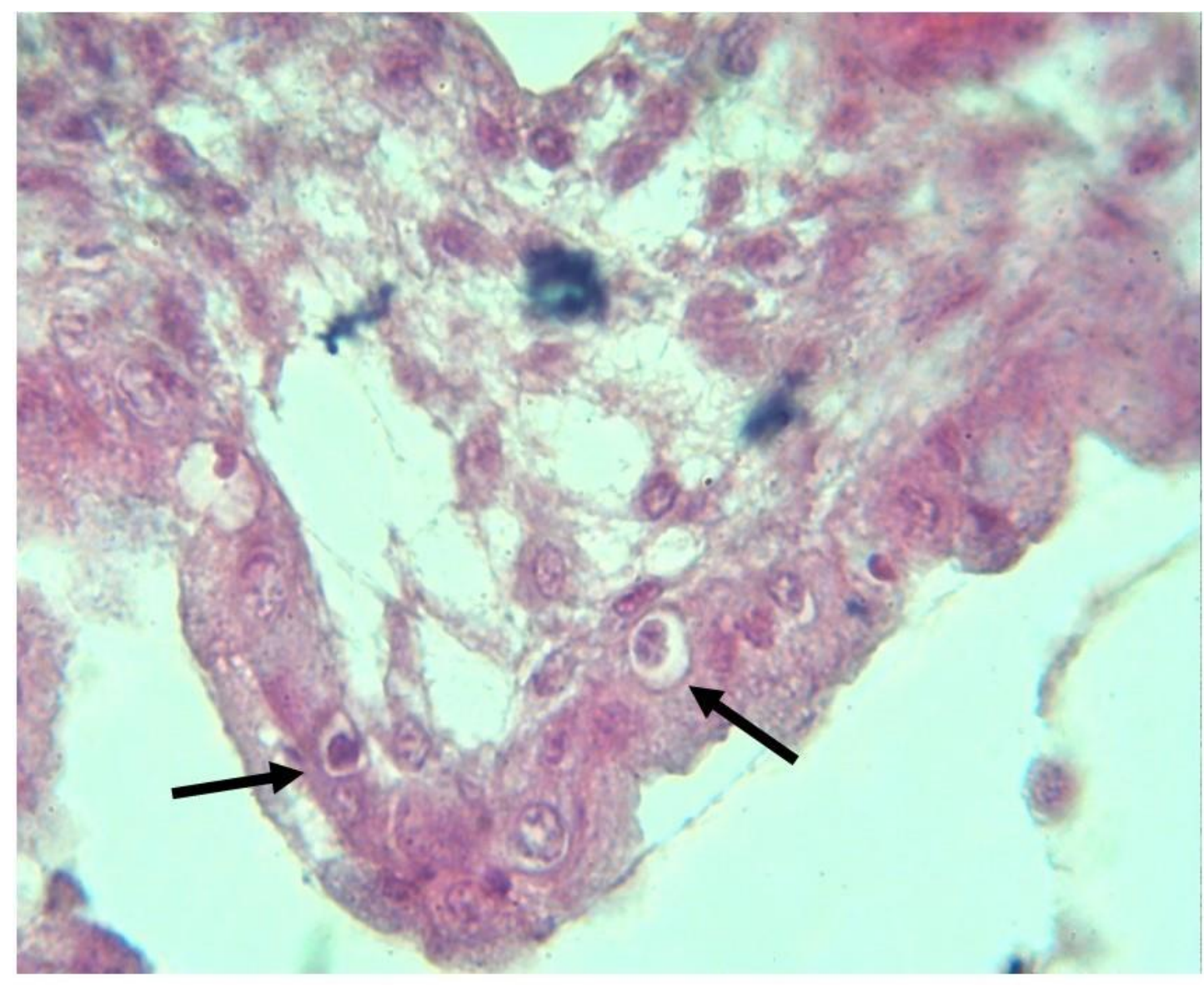

Fig. 5 
A Phylogeny of Envelope protein like gene of Lumpy skin disease virus, Egypt, 2014

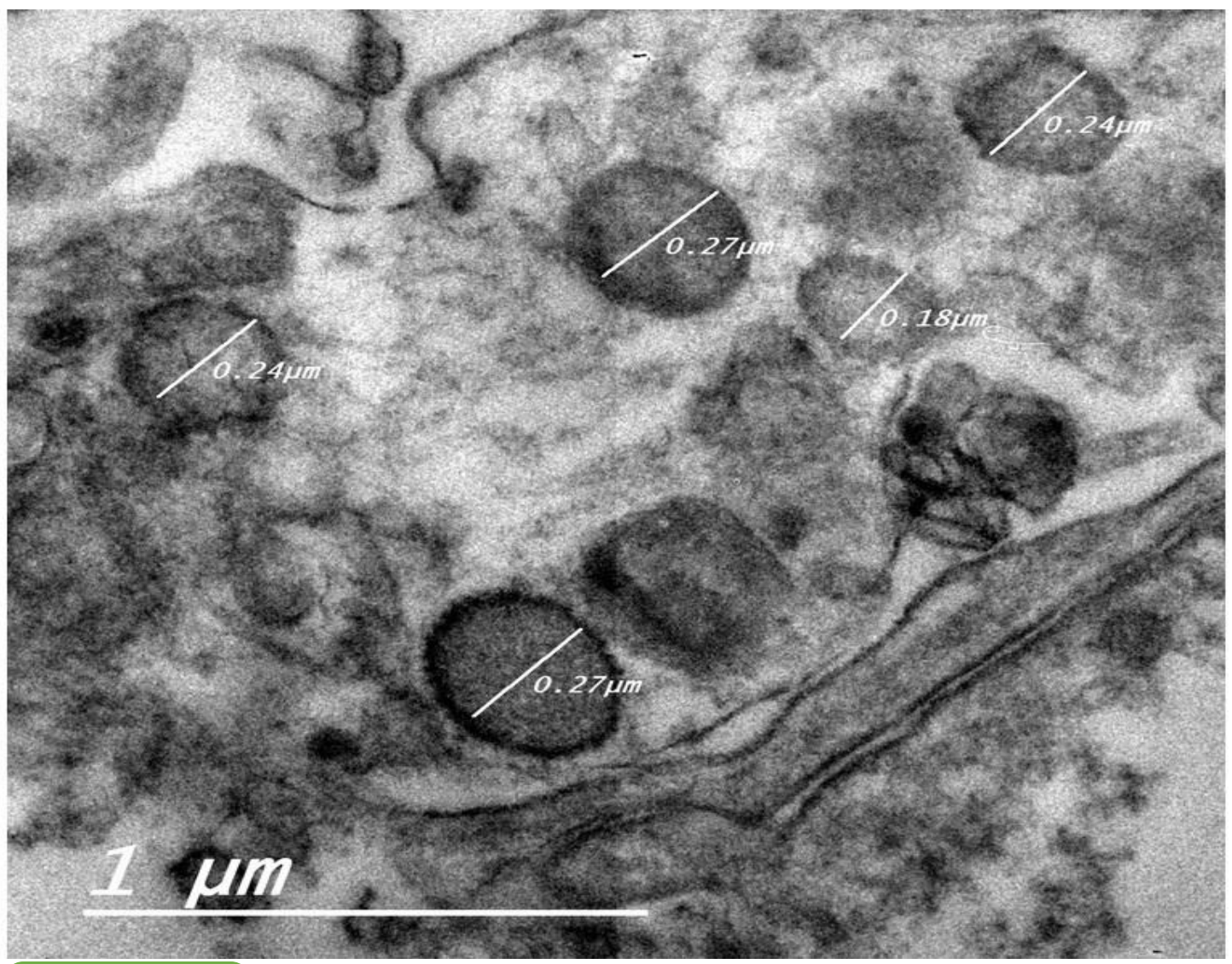

\section{Fig. 6}

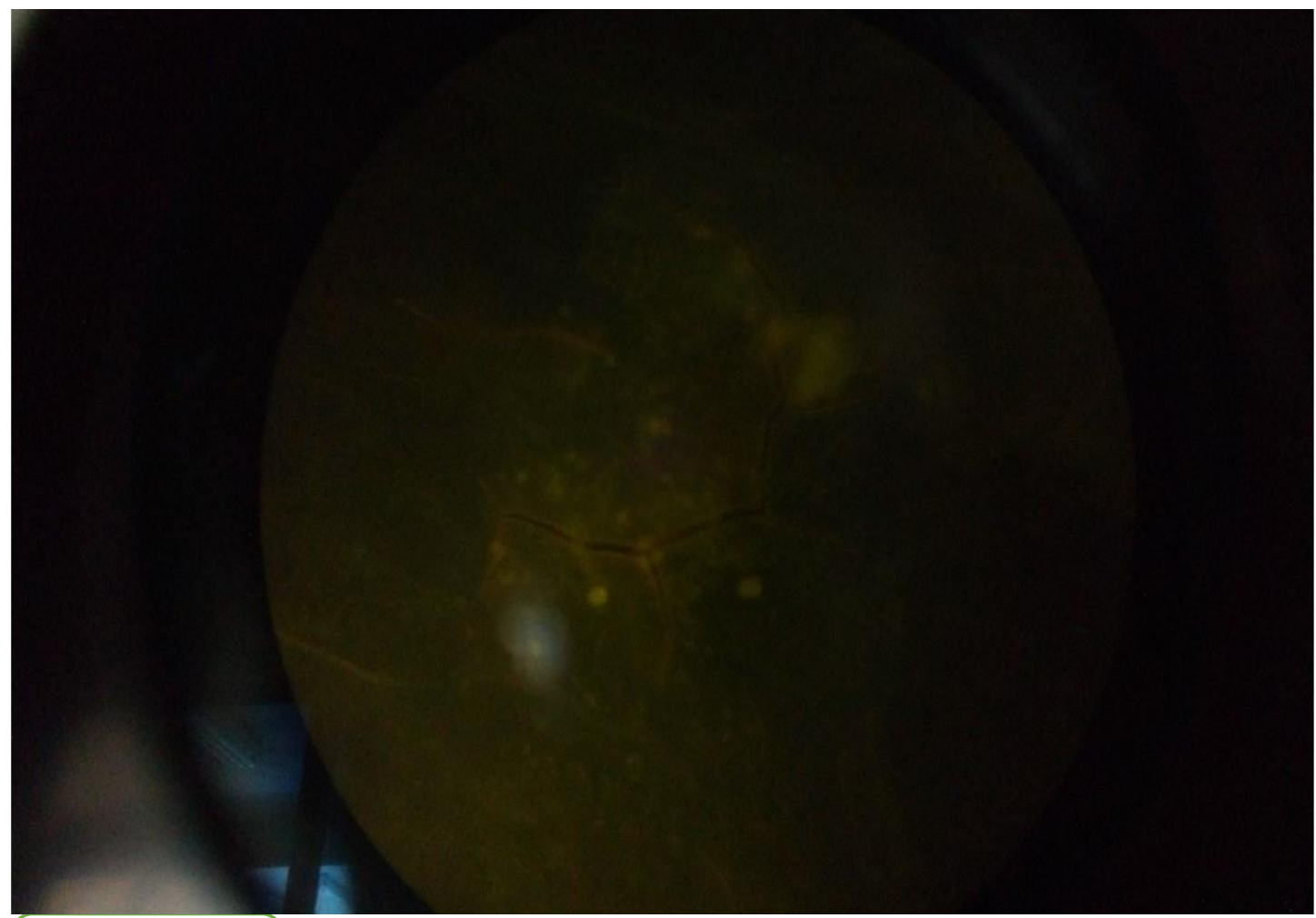

Fig.7 
Fig. 8

\begin{tabular}{llllll}
\hline & 1 & 2 & 3 & 4 & 5
\end{tabular}

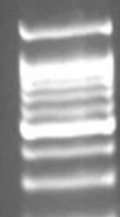

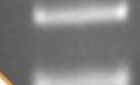
$-$

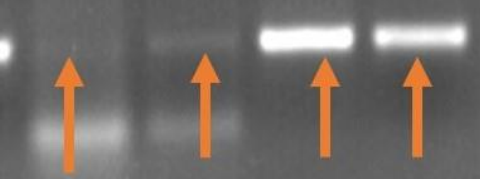

Faint bands

Fig. 9 
Percentldentity

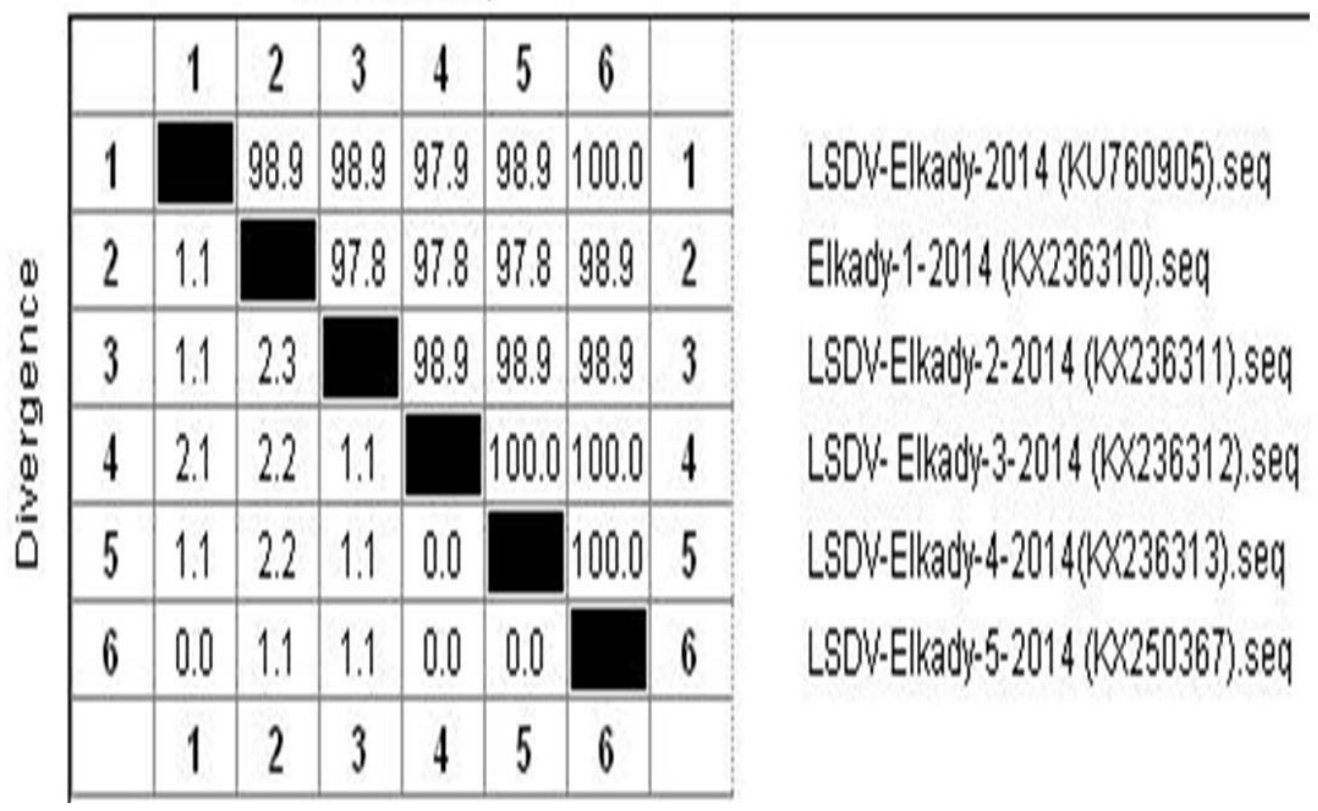

Fig. 10

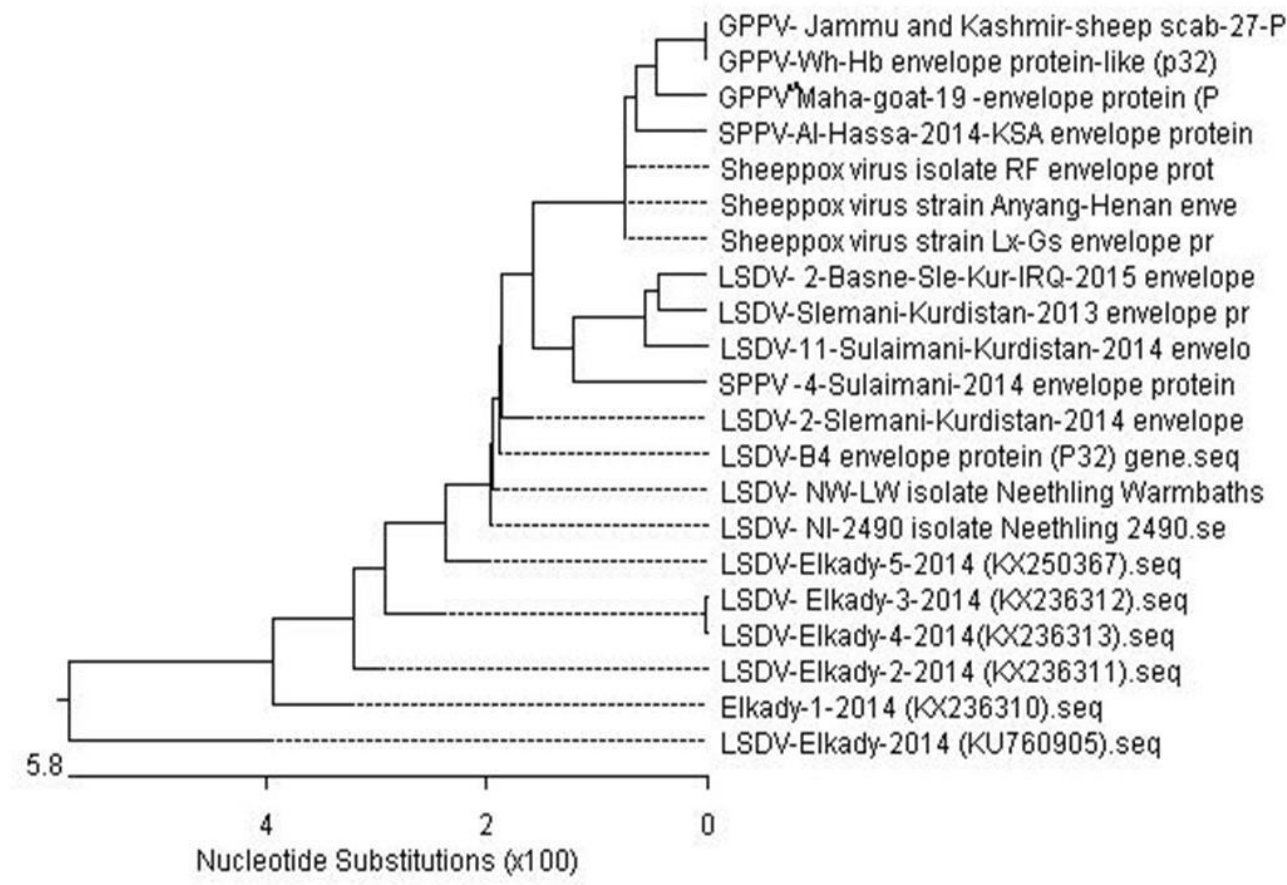

Fig. 11 


\section{List of figure legends:}

Fig-1: Friesian cattle with scabs scattered all over their body parts.

Fig- 2: Hemorrhagic and congested CAMs with pock lesions in the form of stretched white line. Black arrows indicate lesions.

Fig- 3: Hemorrhagic, edematous dead embryos with enlarged, bloody liver and clotted blood inside the heart with slight heart hypertrophy.

Fig_ 4: Egg embryo shows no signs as a negative control.

Fig- 5: Infected CAM, showing large eosinophilic intracytoplasmic inclusion bodies (Black arrows).

Fig- 6: infected CAM, contained ovoid virus particles with rounded ends.

Fig- 7: Specific intracytoplasmic yellowish green fluorescent granules emitted from the infected CAM.

Fig- 8: Specific intracytoplasmic yellowish green fluorescent granules emitted from the infected MDBK cells.

Fig- 9: Electrophoresis of the amplified purified PCR product (113) bp of the envelope protein-like gene for local LSDV strain from different sources. Lane L: High molecular weight nucleic acid marker (100bp), Lane 1: scab suspension, Lane 2: CAM suspension, Lane 3: embryo liver suspension, Lane 4: scab tissue, Lane 5: scab tissue.

Fig- 10: pair wise sequence distance for the envelope protein-like gene of local LSDV strain from different sources.

Fig- 11: phylogenetic tree of local LSDV strain from different sources with the reference LSDV, Sheep pox virus, and goat pox virus published in GenBank based on the partial nucleotide sequence of the envelope protein-like gene.

Table (1): Accession numbers of some isolates of lumpy skin disease virus globally along with sheep and goat pox viruses.

\begin{tabular}{|l|c|}
\hline \multicolumn{1}{|c|}{ ISOLATE } & ACC \\
\hline $\begin{array}{l}\text { Lumpy skin disease virus isolate } \\
\text { ELKADY_2014 envelope protein-like } \\
\text { gene, partial sequence }\end{array}$ & $\underline{\text { KX236310.2 }}$ \\
\hline $\begin{array}{l}\text { Lumpy skin disease virus isolate } \\
\text { ELKADY/1/2014envelope-like protein } \\
\text { gene, partial sequence. }\end{array}$ & \\
\hline $\begin{array}{l}\text { Lumpy skin disease virus isolate } \\
\text { ELKADY/2/2014 envelope-like protein } \\
\text { gene, partial sequence }\end{array}$ & $\underline{\text { KX236311.1 }}$ \\
\hline $\begin{array}{l}\text { Lumpy skin disease virus isolate } \\
\text { ELKADY/4/2014 envelope-like protein } \\
\text { gene, partial sequence }\end{array}$ & $\underline{\text { KX236313.1 }}$ \\
\hline
\end{tabular}




\begin{tabular}{|c|c|}
\hline $\begin{array}{l}\text { Lumpy skin disease virus isolate } \\
\text { ELKADY/3/2014 envelope-like protein } \\
\text { gene, partial sequence }\end{array}$ & $\underline{\mathrm{KX} 236312.1}$ \\
\hline $\begin{array}{l}\text { Lumpy skin disease virus isolate } \\
\text { ELKADY/5/2014 envelope-like protein } \\
\text { gene, partial sequence }\end{array}$ & $\underline{\mathrm{KX} 250367.1}$ \\
\hline $\begin{array}{l}\text { Lumpy skin disease virus NI- } 2490 \\
\text { isolate Neethling 2490, complete } \\
\text { genome }\end{array}$ & AF325528.1 \\
\hline $\begin{array}{l}\text { Lumpy skin disease virus NW-LW } \\
\text { isolate Neethling Warmbaths LW, } \\
\text { complete genome }\end{array}$ & AF409137.1 \\
\hline $\begin{array}{l}\text { Lumpy skin disease virus isolate LSDV- } \\
\text { B4 envelope protein (P32) gene, partial } \\
\text { cds }\end{array}$ & KT253438.1 \\
\hline $\begin{array}{l}\text { Lumpy skin disease virus isolate } \\
\text { LSDV/2/Slemani/Kurdistan/2014 } \\
\text { envelope protein (LSDV074) gene, } \\
\text { partial cds }\end{array}$ & KM047051.1 \\
\hline $\begin{array}{l}\text { Sheeppox virus isolate } \\
\text { Sheeppox/4/Sulaimani/2014 envelope } \\
\text { protein gene, partial cds }\end{array}$ & KP313624.1 \\
\hline $\begin{array}{l}\text { Lumpy skin disease virus isolate } \\
\text { LSDV/11/Sulaimani/Kurdistan/2014 } \\
\text { envelope protein gene, partial cds }\end{array}$ & KP313621.1 \\
\hline $\begin{array}{l}\text { Lumpy skin disease virus isolate } \\
\text { LSDV/Slemani/Kurdistan/2013 } \\
\text { envelope protein (LSDV074) gene, } \\
\text { partial cds }\end{array}$ & $\underline{\text { KF996498.1 }}$ \\
\hline $\begin{array}{l}\text { Lumpy skin disease virus isolate } \\
\text { 2/Basne/Sle/Kur/IRQ/2015 envelope } \\
\text { protein gene, partial cds }\end{array}$ & $\underline{\text { KU720359.1 }}$ \\
\hline $\begin{array}{l}\text { Sheeppox virus strain Lx/Gs envelope } \\
\text { protein (p32) gene, complete cds }\end{array}$ & KJ026555.1 \\
\hline $\begin{array}{l}\text { Sheeppox virus strain Anyang/Henan } \\
\text { envelope protein-like (p32) gene, } \\
\text { complete sequence }\end{array}$ & KJ026553.1 \\
\hline
\end{tabular}




\begin{tabular}{|l|c|}
\hline $\begin{array}{l}\text { Sheeppox virus isolate RF envelope } \\
\text { protein (p32) gene, complete cds }\end{array}$ & $\underline{\text { KJ679574.1 }}$ \\
\hline $\begin{array}{l}\text { Sheep pox virus isolate SPPV/Al- } \\
\text { Hassa/2014/KSA envelope protein (P32) } \\
\text { gene, partial cds }\end{array}$ & $\underline{\text { KP342531.1 }}$ \\
\hline $\begin{array}{l}\text { Goatpox virus isolate Maha/goat/19 } \\
\text { envelope protein (P32) gene, complete } \\
\text { cds }\end{array}$ & $\underline{\text { KF468762.1 }}$ \\
\hline $\begin{array}{l}\text { Goatpox virus strain Wh/Hb envelope } \\
\text { protein-like (p32) gene, complete } \\
\text { sequence }\end{array}$ & $\underline{\text { KJ026558.1 }}$ \\
\hline $\begin{array}{l}\text { Goatpox virus isolate Jammu and } \\
\text { Kashmir/sheep scab/27/P2 envelope } \\
\text { protein (P32) gene, complete cds }\end{array}$ & $\underline{\text { KP702291.1 }}$ \\
\hline
\end{tabular}

\section{Discussion}

According to the findings of this study, the LSDV was isolated from a recent outbreak in Qailubia Province, Egypt amongst cattle populations during 2014. The isolate was able to replicate in CAMs and chick embryo of SPF ECE like the other Egyptian isolate as demonstrated by El-Kenawy et al. (20011), ElNahas et al. (2011), James et al. (1990), Tamam (2006), and Sohair et al. (2008). Although most Egyptian LSDV strains were successfully induce lesion on CAM that varied from thickening and congestion as demonstrated by El- Kenawy et al. (2011) and Sohair et al. (2008) to clearly visible Pock lesion as demonstrated by James et al. (1990) that appeared like numerous, small, scattered white foci as demonstrated by El- Nahas et al. (2011). The surprise by our isolate was its pathologoanatomic signs on the chick embryos in addition to their lesion on CAM indicating a novel biological characteristic not observed by other Egyptian LSDV strains. This characteristic could be expected as LSDV encodes five proteins containing ankyrin repeat motifs that have been associated with host range functions and inhibit virally induced apoptosis as demonstrated by Tulman et al.
(2001), Mossman et al. (1996), and Shchelkunov et al. (1998).

The histopathology and transmission electron microscopy confirm LSDV detection as demonstrated by Tageldin et al. (2014) and help in the differentiation between LSD and pseudo-LSD caused by bovine herpesvirus 2 as demonstrated by MacLachlan et al. (2011).

Gari et al. (2008) demonstrated that IFAT has high accuracy to be used in the diagnosis and sero-surveillance analysis of LSD in the target population. The IFAT was able to detect and identify LSDV antigen in infected CAM and MDBK cells that infected by chick embryo homogenate emphasis the responsibility of the virus on the pathologoanatomic signs observed on CAM and chick embryo.

LSD, Goat pox, and Sheep pox viruses are serologically identical, and so their specific identification relies exclusively on the use of molecular tools as demonstrated by Le Goff et al. (2009). Although recent molecular studies suggest that the Capri poxvirus genus, including SPPV, GTPV, and LSDV are very similar in terms of antigenic characteristics, those viruses are phylogenetically distinct and can be differentiated by accurate molecular 
techniques as demonstrated by Bhanuprakash et al. (2006).

The local LSDV strain from different sources was sequenced, and Clustal analysis based on the envelope protein-like gene showed $98 \%$ to $100 \%$ identity of the virus in different sources. High nucleotide similarity of the strain in their different sources were showed with LSDV- NI-2490 isolate Neethling 2490 (AF325528), LSDV/ NW/LW isolate Neethling Warmbaths LW (AF409137), LSDV/2/Slemani/Kurdistan/2014 envelope (KM047051), and LSDV-B4 envelope protein (P32) gene (KT253438). Both LSDV- NI-2490 isolate Neethling 2490 (AF325528) and LSDV/ NW/LW isolate Neethling Warmbaths LW (AF409137) revealed percent homology of $100 \%$ with LSDV-Elkady-52014 (KX250367), 94.3\% with LSDVElkady-2014 (KU760905), and 98.9\% with other strain sources, including LSDV-Elkady1-2014 (KX236310), Elkady-2-2014 (KX236311), LSDV-Elkady-3-2014 (KX236312), and LSDV-Elkady-42014(KX236313). This homology emphasis the theory of Kara et al. (2003) who mentioned that Capri pox virus genomes sequences are highly conserved, and there is more than $95 \%$ homology amongst LSD, sheep pox, and goat pox viruses. Moreover, Tulman et al. (2001) recorded extremely conserved Capri pox virus isolates genome with identities of at least $96 \%$.

Our phylogenetic tree grouped viruses of LSD, Sheep pox, and Goat pox viruses separately, and our strain resources were related to each other and to the other LSDV, including LSDV- NI-2490 (AF325528), LSDV/ NW/LW (AF409137), LSDV/2/ Slemani/Kurdistan/2014 (KM047051), and LSDV-B4 (KT253438).

\section{Conclusions:}

It is safe to conclude that, there may be a novel LSDV isolate in Egypt which uniquely shared the same characteristic partial sequence about 113bp with LSDV- NI-2490 Neethling isolate and LSDV/2/Slemani/Kurdistan/2014. And it differs in biological properties in embryonated eggs. So further molecular sequencing for more specific sufficient target was needed. In addition, cross neutralization using monoclonal antibodies between our strain and the Neethling type recommended.

\section{Compliance with Ethical Standards:}

Ethics approval and consent to participate: All applicable international, national, and/or institutional guidelines for the care and use of animals were followed. This article does not contain any studies with human participants by any of the authors.

Consent for publication: "Not applicable". Availability of data and material: Data sharing not applicable to this article as no datasets were generated or analysed during the current study. "Please contact author for data requests."

Competing interests: "The authors declare that they have no competing interests."

Funding: all fund from author Gehad Elkady in the design of the study and collection, analysis, and interpretation of data and in writing the manuscript

Authors' contributions: Gehad elkady carried out the practical work, Gabr elbagoury carried out writing introduction and conclusion, Ehab elnahas carried out writing results and discussion, Ayman elhabaa carried out writing material and method. All authors read and approved the final manuscript.

\section{Acknowledgements:}

I would like to extend my best regards to DrMohamed Gouda Abd -Elwahab, Associate Professor of Infectious Diseases, Faculty of Veterinary Medicine, Benha University, DrWessel Dirksen, Laboratory manager at Ohio state, and Dr. Saeed Elshafae, Lecturer of Pathology, Faculty of Veterinary Medicine, 
Benha University for their help to design the primers.

\section{References}

AA EL-Kenawy and MS EL-Tholoth., 2011. Lumpy skin disease virus identification in different tissues of naturally infected cattle and chorioallantoic membrane of embryonated chicken eggs using immunofluorescence,

immunoperoxidase techniques and polymerase chain reaction. IJV 7, 158166.

Bhanuprakash V, Indrani BK, Hosamani M, Singh RK., 2006.The current status of sheep pox disease. Comp. Immunol. Microbiol. Infect 29, 27-60.

Buller RM, Arif BM, Black DN, Dumbell KR, Esposito JJ, Lefkourtz EJ, McFadden G, Moss V, Mercer AA, Moyer RW. et al., 2006. Poxviridae in virus taxonomy. VII the report of the International Committee on Taxonomy of viruses. Academic Press, pp. 117-133.

Chihota CM, Rennie LF, Kitching RP, Mellor PS., 2001. Mechanical transmission of lumpy skin disease virus by Aedes aegypti (Diptera: Culicidae). Epidemiol. Infect 126, 317-321.

Davies FG, Krauss H, Lund J, Taylor M., 1971. The laboratory diagnosis of lumpy skin disease. Research in Veterinary Science 12, 123-127.

El-Bagoury GF, Madbouly HM, Iman AA, Farrag, Saber MS., 1995. Isolation and characterization of Lumpy skin disease (LSD) virus from cattle during natural outbreak in Minia Governorate. Alex. J. Vet. Sci 11, 167-174.

ER. Tulman, C L. Afonso, Z. LU, L. Zsak, G. F. Kutish, D. L. Rock., 2001. Genome of Lumpy Skin Disease Virus. JVI 75 , 7122-7130.

El-Nahas, AS El-Habbaa, GF El-bagoury, Mervat EI Radwan., 2011. Isolation and identification of lumpy skin disease virus from naturally infected buffaloes at Kaluobia, Egypt. Global Vet 7, 234237.

Gari G, Biteau- Coroller F, LeGoff C, Caufour P, Roger F., 2008. Evaluation of indirect fluorescent antibody test (IFAT) for the diagnosis and screening of lumpy skin disease using Bayesian method. Vet Microbiol 129, 269-280.

Haligur M, Ozmen O, Vural SA, Berkin S., 2009. Pathological, immunohistochemical and electron microscopical examinations on chorioallantoic membrane lesions in experimental fowl poxvirus infection. Kafkas Üniversitesi Veteriner Fakültesi Dergisi 15, 345-350.

James A. House, Terrance M. Wilson, Sinan El Nakashly, Ikram A. Karim, Ibrahim Ismail, Nabil El Danaf, Aly M.Moussa, Nazmi N. Ayou., 1990. The isolation of lumpy skin disease virus and bovine herpesvirus- from cattle in Egypt. J Vet Diagn Invest 2, 111-115.

Le Goff C, Lamien CE, Fakhfakh E, Chadeyras A, Aba-Adulugbad E, Libeau G, Tuppurainen E, Wallace D, Adam T, Silber R. et al., 2009. Capripoxvirus Gprotein-coupled chemokine receptor, a host-range gene suitable for virusanimal origin discrimination. J. Gen. Virol 90, 1967-1977. 
Miller SE., 1995. Diagnosis of viral infection by electron microscopy. In: $\mathrm{EH}$ Lennette, DA Lennette, ET Lennette (ed) Diagnostic procedures for viral, rickettsial, and chlamydial infections, 7th edn. American Public Health Association, Washington, DC, pp. 3778.

Mossman K, Lee SF, Barry M, Boshkov L, McFadden G., 1996. Disruption of MT5, a novel myxoma virus gene member of poxvirus host range superfamily, results in dramatic attenuation of myxomatosis in infected European rabbits. J. Virol 70, 4394-4410.

MacLachlan NJ, Dubovi EJ., 2011. Poxviridae. In: MacLachlan NJ, Dubovi EJ (ed) Fenner's veterinary virology, 4th edn. London, Boston Academic press, pp.157-160.

Mohamed Hassan Tageldin, David Brian Wallace, Gertruida Hermanna Gerdes, John Fraser Putterill, Roelf Rudolph Greyling, Maanda Noaxe Phosiwa, Rashied Mohammed Al Busaidy, Sultan Issa Al Ismaail, 2014. Lumpy skin disease of cattle: an emerging problem in the Sultanate of Oman. Trop Anim Health Prod 46,241-246.

OIE., 2010. Terrestrial Manual of Lumpy Skin

Disease, Chapter 2.4.14. Version adopted by the World Assembly of Delegates of the OIE.

PD Kara, CL Afonso, DB Wallace, GF Kutish, C Abolnik, Z Lu, FT Vreede, LCF
Taljaard, A Zsak, GJ Viljoen., 2003. Comparative sequence analysis of the South African vaccine strain and virulent field isolates of Lumpy skin disease virus. Arch Virol 148, 13351356.

Shchelkunov SN, Safronov PF, Totmenin AV, Petrov NA, Ryazankina OI, Gutoro VV, Kotwal GJ., 1998. The genome sequence analysis of the left and right species-specific terminal region of a cowpox virus strain reveals unique sequences and a cluster of intact ORFs for immunomodulatory and host range proteins. J. Virol 243, 432-460.

SM Tamam., 2006. Isolation of Lumpy skin disease virus from naturally infected cattle previously vaccinated with live attenuated sheep poxvirus vaccine. BS. VET. MED. J 16,27-31.

StramY, Kuznetzova L, Friedgut O, Gelman B, Yadin H, Rubinstein-Guini M., 2008. The use of lumpy skin disease virus genome termini for detection and phylogenetic analysis. J Virol Meth 151, 225-9.

Sohair I Badr, Ibrahim EM, Shahein MA., 2008. Virological and pathological studies on lumpy skin disease in naturally infected cattle, Egypt. J. Comp. Path. \& Clinic. Path 1, 446- 465.

Tamura K, Dudley J, Nei M, Kumar S., 2007. MEGA4: Molecular evolutionary genetics analysis (MEGA) software version 4.0. Mol. Biol. Evol 24, 1596 1599. 